\title{
Vertical and Horizontal Integration in the Profitability of Malaysian Broiler Firms
}

\author{
Y. S. Tey \& P. Arsil b,* \\ ${ }^{a}$ Institute of Tropical Agriculture and Food Security, Universiti Putra Malaysia, \\ 43400 UPM Serdang, Selangor, Malaysia \\ ${ }^{b}$ Faculty of Agriculture, Universitas Jenderal Soedirman, \\ 53122 Karangwangkal, Purwokerto, Central Java, Indonesia \\ *Corresponding author: poppy74arsil@gmail.com \\ (Received 20-06-2020; Revised 09-08-2020; Accepted 21-09-2020)
}

\begin{abstract}
Vertical integration has been widely promoted for offering production, transaction, and market benefits in the poultry industry. These benefits must be translated into profitability - a proxy of competitive advantage. This study aimed to identify the financial effect underlying the degree of backward, forward, and horizontal integration, alongside the financial strength and management capability of broiler firms. We used random-effects general least squares to analyze a panel dataset of broiler firms that publicly listed in Kuala Lumpur Stock Exchange Malaysia for the 2006-2018 period. Support is found for the hypothesis that forward integration enhanced profitability. In comparison, the operating margin had a greater influence on broiler firms' financial performance. Notwithstanding value chain development, the relative findings suggest that efficiency remains a priority in a commodity-based broiler market. It is thus recommended that management capability be emphasized.
\end{abstract}

Keywords: broiler; integration; value chain; financial performance

\section{INTRODUCTION}

Vertical integration is the most common form of organization in the global poultry industry (Barbut, 2016). A high degree of vertical integration and contractual relationship has accelerated its industrialization in developed countries (Constance et al., 2013). Technological advancement has further contributed to the improved efficiency in terms of cost and feed efficiency and output per worker (Lotterman, 1998). These factors have led to a decline in poultry's relative market prices compared to the other meats. A reliable source of affordable animal protein is now available to consumers (FAO, 2008). Towards improving aggregate consumer welfare, vertical integration continues to be on the agenda of poultry industrialization in developing countries (OECD, 2018). Meat-based protein demand is anticipated to rise in tandem with income growth.

Vertical integration of the poultry value chain presents a strategic proposition, based on three important considerations: (1) biosecurity and quality, (2) economies of scale and margin control, and (3) market share and capital optimization (Henry \& Rothwell, 1995; Dobashi et al., 1999). First, vertical integration facilitates poultry firms to monitor strict biosecurity measures, along with production and procurement processes and quality attributes in a changing market environment, such as those of consumer preference, desired quality, and convenience of preparation or consumption.
Second, vertical integration involves agglomeration (of on- and off-farm activities within a geographic location) that can reduce various transaction costs (money and time), leading to economies of scale and improved margins. Both of these come about from a reduction in production and marketing costs with an improved ability to produce and procure poultry products in a larger volume. Third, vertical integration allows poultry firms to deploy capital resources and command market share of other stages of the value chain in which the companies did not previously participate.

Although vertical integration (or the lack of it) can have a significant impact on the poultry business, research interest in understanding its influence on financial performance and competitiveness has been scant (Riethmuller \& Chalermpao, 2002). This is important since firm-specific characteristics render an explanation to the financial performance of agri-food firms (e.g., Hirsch et al., 2014; Hirsch \& Schiefer, 2016; Blažková \& Dvouletý, 2018). For example, financial risks such as leverage that incur costs reduce profitability (Gschwandtner \& Hirsch, 2018; Grau \& Reig, 2020). In addition, Chaddad \& Modelli (2013) indicate that business strategy reinforces the returns. Value chain integration is one such strategy (Grau \& Reig, 2019). Bhuyan (2002) found poultry slaughtering and processing companies that presented a higher-than-average forward vertical integration index had a lower return than the industry average. Bhuyan's (2005) follow-up study shows 
that forward vertical integration strengthens market power to a level that is above the average of American food manufacturing industries. More specifically, Bamiro \& Shittu (2009a) found that vertical integration helped optimize feed and veterinary inputs, reduced labor input, and improved productivity in the Nigerian poultry industry. Bamiro \& Shittu (2009b) prove integrators enjoy higher return rates on investment than partial and non-integrators.

This study thus aims to investigate the financial performance resulted from different integration types and the degree of integration undertaken by poultry firms. Backward/forward vertical integration occurs when firms acquire and take over a process typically done earlier/later in the base activity. For a firm that has poultry farming as its core segment, backward integration involves investment in feed milling, pharmaceuticals, and/or breeding of grandparent stocks, parent stocks, and/or day-old chicks; forward integration involves investment in processing, manufacturing, distribution, and/or retailing. Modern poultry firms may also have undertaken horizontal integration by converting their wastes into by-products, such as biogas, fertilizers, and livestock feeds. These different types of integration are known as value chain integration. Uncovering their degree of integration in relation to investment outcome would help provide a better knowledge of their financial potential, which provides a reflection of their competitive edge and its durability in the commodity business.

To identify the financial effects of underlying degrees of value chain integration types undertaken by poultry firms, this study uses Wernerfelt's (1984) resource-based view (RBV) model to analyze panel data of publicly listed broiler firms of Malaysia. These broiler firms' production has so far specialized in standard broiler - a strategic food product for food security (Hoffmann, 2005). Malaysian consumers continue to prefer standard broilers in the forms of whole fresh birds and their fresh cuts (Abdul Hadi et al., 2013). These broiler firms thus seek to diversify their business segments through integration (Baluch et al., 2017). More players are anticipated to become integrators (Muazu et al., 2016). Notwithstanding that, it remains unclear whether the strategic move can raise their competitiveness and returns. The RBV thus becomes relevant given that it ascribes varied financial performance of firms to asymmetric strategic considerations and their quality. Past studies used this model to identify the impact of various strategic resources on financial returns. Recently, Tey et al. (2020) applied RBV analysis to examine the financial outcome and, ultimately, the early-mover advantage of plantation firms' decisionmaking with respect to order of certification. Closer to the subject of this study, Chang et al. (2016) employed the RBV model to synthesize the advantageous financial effect of supply chain integration, involving close coordination between suppliers and customers. The motivation for using the RBV model in this study is to facilitate better understanding of performance drivers, including operating efficiency (a proxy for management) that is inherent in commodity businesses. On this basis, the RBV model is appealing as it allows this investigation to navigate both resource strengths and strategies that are of importance to business success.

Both policymakers and poultry firms would benefit from the objective of this study to examine the financial changes and competitive edge that value chain integration brings about in poultry industry. In particular, value chain integration has been posited as a solution for overcoming weak business links and synergizing operations in order to generate a joint advantage greater than the sum of effects achieved separately. However, for poultry firms, value chain integration presents a strategic option that is often capital intensive, risky, and almost irreversible. Therefore, understanding of its financial returns provides important input to their decision-making since value chain integration involves voluntary adoption. The evidence which this study aims to obtain is critical to maintaining legitimacy of vertical integration in underpinning poultry industrialization for improved consumer welfare.

\section{METHODS}

In its original form, the RBV model offers a managerial framework for employing strategic resources for firms to enhance their financial returns through improved competitive advantage (Barney, 1991). Because firms possess heterogenous resources, their quality is of strategic importance. Investments such as those undertaken for vertical integration and horizontal integration deploying strategic resources are thus made for the returns that will improve their existing financial wellbeing and sustainability. A direct relationship exists between strategic resources and financial performance.

The RBV model can thus facilitate understanding of the financial performance of broiler firms in relation to their integration investments, i.e., the impact of backward integration, forward integration, and horizontal integration on profitability (e.g., Monsur \& Yoshi, 2012). It has also been used to understand the influence of a reduction in the level of vertical integration through outsourcing (e.g., Espino-Rodríguez \& Padrón-Robaina, 2005). Therefore, it is a relevant framework for identifying their relationship and magnitude of association. Used in the context of broiler firms' financial outcomes in relation to integration strategies, the RBV model posits that boundary expansion through integration initiatives is undertaken for strategic use in return for sustainable return on invested capital - a common metric of competitive advantage.

As noted previously, Wernerfelt (1984) related the financial performance of firms to their heterogeneous resources. This terminology is useful in our analysis since the RBV approach involves the identification of a range of degrees of financial position, management capability, and strategic business integration - variables that a firm can control readily in directing a financial outcome, i.e., how they affect the returns, and the extent of their effect. The function of profitability can thus be conceptualized as:

$R O I C=f(m i, f p, m c)$ 
where ROIC denotes the financial performance of a broiler firm, mi denotes a vector of variables describing market integration, $f p$ denotes a vector of variables describing financial position, and $m c$ denotes a vector of variables describing management capability.

Return on invested capital (ROIC) is used as a measure of profitability in this study. It measures operating profit against the invested capital of a firm. In other words, it assesses a firm's efficiency at allocating capital to profitable investments (Koller et al., 2010a, 2010b). Compared to another popular metric, return on equity (ROE), the ROIC is not affected by a firm's chosen capital structure and share buybacks. The ROIC also enables a relative comparison to the cost of capital in totality, which is measured by the weighted average cost of shareholder equity and bank borrowings, for determining economic profit or loss. In the case of ROE, only the cost of shareholder equity is considered. Therefore, ROIC is widely regarded as the fairest measure of profitability (Damodaran, 2007). High and sustained ROIC is a generally accepted inference of durable competitive advantage (Brilliant \& Collins, 2014).

The abovementioned concepts of ROIC concur with the financial performance and competitive advantage notions underlying the RBV model in attributing value to various strategic resources firms possess. How these resources are allocated is critical to both outcomes. The decision to integrate broiler farms with a feed mill, for example, involves intensive capital investment to acquire the associated plant, property, and equipment in return for improved efficiency along with the upstream. Such decomposition of ROIC into its nominator (operating efficiency) and denominator (invested capital efficiency) addresses the resource optimization behavior of firms as posited by the RBV model.

\section{Empirical Model}

Using ROIC as the dependent variable, the following random-effects general least squares regression was estimated:

$$
\begin{aligned}
\text { ROIC }_{i t}= & c_{0}+\beta_{1} D B I_{i t}+\beta_{2} D F I_{i t}+\beta_{3} D H I_{i t}+\rho_{1} D A R_{i t}+\rho_{2} C R_{i t}+ \\
& \delta_{1} O M_{i t}+\delta_{2} I C A R_{i t}+e_{i t}
\end{aligned}
$$

where ROIC $_{i+}$ is return on invested capital for the $i$ th firm in the $t$ th year; $D B I_{i t}$ is the degree of backward integration; $D F I_{i t}$ is the degree of forward integration; $D H I_{i t}$ is the degree of horizontal integration; $D A R_{i t}$ is the debt-to-asset ratio; $C R_{i t}$ is the current ratio; $O M_{i t}{ }_{i t}$ is the operating margin; $I C A R_{i t}$ is the invested capital-to-asset ratio; and $e_{i t}$ is an error term. In this model, individual unobserved heterogeneity was not correlated with the independent variables.

The degree of backward integration $(D B I)$, the degree of forward integration (DFI), and degree of horizontal integration $(D H I)$ are direct measures for the respective type of integration. The degree of integration is defined by the number of stages in the value chain segment firms have ventured into as a proportion of the total segment stages. Because broiler farming is the fundamental base, it was not counted. For example, there are four stages in the downstream segment of the
Malaysian broiler value chain: processing, manufacturing, distribution/wholesaling, and retailing. A firm in an observation year was assigned 0.5 point for involvement in two out of the four downstream stages. As discussed at the outset, backward integration, forward integration, and horizontal integration present respective distinctions in boundary expansion. Such a direct measure of the degree of vertical integration is similar to that of previous studies (for example Minkler \& Park, 1994). Irrespective of their strategic directions, they unite to serve the resource optimization objective for strengthening their profitability (competitiveness). An expectation is thus shaped that broiler firms which ventured further into a value chain segment would generate greater returns than those involved in a lower range. Nevertheless, it is acknowledged that all forms of integration are an asset- and skill-intensive, and they may tilt the financial outcome to a different direction.

Financial wellbeing characteristics were included to assess the effects of solvency and liquidity on financial performance. Debt-to-asset ratio $(D A R)$ measures the portion of total assets that are financed by both long and short-term borrowings instead of shareholder equity. In choosing a capital structure, management of broiler firms have the option to finance investment through either source of funding. As represented by this variable, the borrowing instrument has fixed rules in which creditors have a primary claim over the firms' assets during liquidation. A higher ratio is suggestive of a higher degree of leverage and, thus, higher interest costs that reduce net income. While this seems like a trade-off, the deployment of borrowings represented by a high debt-to-asset ratio may generate a return above its cost of capital. Current ratio $(C R)$ measures the ability of current assets to meet the short-term liabilities of a firm instead of relying on cash flows. In ensuring liquidity, the management of broiler firms decides whether to maintain just working capital or to also save extra liquid capital in preparation for future investment or risk opportunities. Without being put to economic use, excess capital that is often represented by a high current ratio is expected to dampen a firm's profitability returns (Saleem \& Rehman, 2011).

As with management capability, efficiencies in managing operations and allocating capital were included in the model. Operating margin $(O M)$ measures how much profit a firm makes on a dollar of sales after paying for production and operation expenses, vis-à-vis deducting for depreciation and amortization of assets. Half of that concerns cost control, and the other half is related to maintenance of asset quality. Efficiency in this manner extracts more dollars of sales into a profit. Therefore, a positive relationship is anticipated between operating margin and financial returns (Rani et al., 2005). Invested capital-to-asset ratio (ICAR) measures the value of assets a firm allocates for economic use, in the forms of fixed assets (properties, plants, and equipment) and working capital. The former relates to the capital necessary for investing in an operational base, and the latter is intended for supporting its daily operations. Efficient capital allocation deploys a smaller sum of invested capital relative to the firm's total assets to 
generate sales. In this sense, the ICAR is expected to be inversely associated with financial returns. The $O M$ and ICAR represent management capability -proxies of an intangible asset.

\section{Panel Data}

In this study, the data collection process was split into three stages. First, because there is no poultry stock market index, a general search was necessitated to identify poultry firms listed on the Kuala Lumpur Stock Exchange. To facilitate this process, we read through equity research reports on the poultry industry that were published by numerous investment banks. Collectively, a total of 11 firms were shortlisted. Second, we retrieved their annual reports and read through their financial statements and notes. Among all this information, information on segmental results was referenced to determine the degree of sales contribution deriving from the broiler business. A total of seven firms with broiler-related business as a core contributor to group revenue (more than 50\%) were retained. Third, market integration information and financial ratios were collected through text identification in annual reports and Thomson Reuters' Data stream system, respectively.

The collected annual data presented a balanced panel dataset capturing seven broiler firms' observations for the 2006-2018 period. It is noted that this sample was not randomly drawn. Despite the fact that they were not representative of average broiler firms, these companies were among the first to embark on integration initiatives. Therefore, their experience provides critical insights into the issue of business integration in relation to industrialization. Such efforts are met with inherent cyclical volatility and, thus, our long-range observation across broiler firms is appealing. The panel dataset helps avoid skewed understanding that is associated with the timing (upturn/downturn) of investigation.

Table 1 presents descriptive statistics of the regression variables for both the start and end years of the 2006-2018 period. The sample had become increasingly integrated through investments in feed mills, veterinary, grand-parent stock, parent stock and/or day-old-chick segments for backward integration; processing, manufacturing, distribution and/or retailing segments for forward integration; fertilizer and/or biogas segments for horizontal integration. In this study period, horizontal integration was a voluntary choice. Local governments have just begun reviewing poultry enactments and regulations on whether to make closed poultry houses and waste treatment mandatory. However, the financial performance of the sample broiler firms had deteriorated from a thin profitability of $4.9 \%$ to a loss of $-1.37 \%$ amid expanding variance from the means. A similar trend was observed for their operating margins, although more assets were allocated for capital investment. Notwithstanding that, their business was increasingly solvent, as indicated by the shrinking debt-to-asset ratios, and had improved liquidity based on the rising current ratios.

\section{RESULTS}

Our analysis began with the screening of data properties using the panel dataset. Since there was no endogeneity issue between the independent variables, both fixed and random-effects general least squares regressions (Equation 2) were estimated. A post-estimation Hausman test revealed that the random-effects model was statistically appropriate.

Table 2 presents the statistical output of the random-effects general least squares regression. The $\mathrm{R}$-square value indicated that the independent variables explained $81 \%$ of the variance in the ROIC of the sample broiler firms. The coefficients were significant when taken jointly based on the chi-square statistics (338.13, $\mathrm{p}<0.001)$. Therefore, the model presented a reasonable fit. An elasticity measure of each independent variable's means was also presented to complement the typical understanding rendered by the coefficients. This measured the proportional change of the dependent variable (ROIC) in response to a change in an independent variable while other things are assumed to remain constant. In that sense, the relative change perspective of elasticity is immune to varied measurement units and allows direct comparability across variables.

Of all forms of business integration, the degree of forwarding integration (0.0598) had a highly significant $(p<0.001)$ positive influence on ROIC. There was a difference in financial performance with respect to the depth of ventures into the downstream segment. On average, its elasticity measure of 0.5778 suggests that a $10 \%$ increase in the post-farm involvement would generate

Table 1. Descriptive statistics of the beginning (2006) and ending (2018) of the panel period

\begin{tabular}{|c|c|c|c|c|c|}
\hline & \multirow{2}{*}{ Unit } & \multicolumn{2}{|r|}{2006} & \multicolumn{2}{|r|}{2018} \\
\hline & & Mean & Standard deviation & Mean & Standard deviation \\
\hline Return on invested capital (ROIC) & $\%$ & 4.8833 & 5.4636 & -1.3650 & 19.4296 \\
\hline Degree of backward integration (DBI) & - & 0.54286 & 0.15119 & 0.60000 & 0.12649 \\
\hline Degree of forward integration (DFI) & - & 0.53571 & 0.17252 & 0.70833 & 0.24580 \\
\hline Degree of horizontal integration (DHI) & - & 0.07143 & 0.18898 & 0.25000 & 0.41833 \\
\hline Debt-to-asset ratio (DAR) & - & 0.43833 & 0.07885 & 0.28500 & 0.04324 \\
\hline Current ratio (CR) & - & 0.85667 & 0.18490 & 1.47667 & 0.84939 \\
\hline Operating margin (OM) & $\%$ & 3.1178 & 3.3512 & 0.9081 & 14.7822 \\
\hline Invested capital-to-asset ratio (ICAR) & - & 0.66088 & 0.23248 & 0.80690 & 0.37167 \\
\hline
\end{tabular}


Table 2. General least squares analysis on return on invested capital of broiler firms

\begin{tabular}{|c|c|c|}
\hline & $\begin{array}{c}\text { Coefficient } \\
\text { (Standard error) }\end{array}$ & $\begin{array}{c}\text { Elasticity } \\
\text { (Standard error) }\end{array}$ \\
\hline \multirow[t]{2}{*}{ Constant } & 0.0611 & - \\
\hline & $(0.0544)$ & - \\
\hline \multirow[t]{2}{*}{ Degree of backward integration (DBI) } & -0.0597 & -0.5297 \\
\hline & $(0.0461)$ & $(0.4108)$ \\
\hline \multirow[t]{2}{*}{ Degree of forward integration (DFI) } & $0.0598^{* * *}$ & $0.5778^{* * *}$ \\
\hline & $(0.0179)$ & $(0.1778)$ \\
\hline \multirow[t]{2}{*}{ Degree of horizontal integration (DHI) } & -0.0200 & -0.0570 \\
\hline & $(0.0161)$ & $(0.0462)$ \\
\hline \multirow[t]{2}{*}{ Debt-to-asset ratio (DAR) } & -0.0863 & -0.5161 \\
\hline & $(0.0531)$ & $(0.3199)$ \\
\hline \multirow[t]{2}{*}{ Current ratio $(\mathrm{CR})$} & $-0.0277^{*}$ & $-0.4390^{*}$ \\
\hline & $(0.0162)$ & $(0.2589)$ \\
\hline \multirow[t]{2}{*}{ Operating margin (OM) } & $1.2378^{* * *}$ & $1.2378^{* * *}$ \\
\hline & $(0.1001)$ & $(0.1000)$ \\
\hline \multirow[t]{2}{*}{ Invested capital-asset ratio (ICAR) } & 0.0057 & 0.0561 \\
\hline & $(0.0183)$ & $(0.1785)$ \\
\hline \multicolumn{3}{|l|}{ R-square $=0.8126$} \\
\hline Chi-square $=338.13(p$-value: 0.001$)$ & & \\
\hline
\end{tabular}

Notes: ${ }^{* *}$ and ${ }^{*}$ denote statistical significance at the $1 \%$ and $10 \%$ levels, respectively.

a greater return by approximately $5.78 \%$. This positive association is in line with our expectations, but the change is considered inelastic in the economic term. One possible explanation is that heavy capital investment is needed to acquire assets for starting up a value-adding operation, such as modern processing plants (first processing stage), food manufacturing plants (second processing stage), warehouse storage and distribution transport, and to retail outlets. Undifferentiated fresh broiler products remain the top preference in consumers' food baskets, so only a fraction of the output from the first processing stage is being used as a feedstock in the second processing stage. The scale of such valueaddition remains a key issue and has limited the optimization of economic resources that broiler firms have invested in distribution and/or retailing. Nevertheless, forward integrators still outperformed laggards, who were constrained by their chosen (invested) assets to produce only slightly or non-differentiated broiler products.

Current ratio (-0.0277) was the only significant $(\mathrm{p}<0.100)$ financial wellbeing characteristic. Sample broiler firms with greater current assets relative to current liabilities experienced lower ROIC. An elasticity measure of -0.4390 suggests that a $10 \%$ increase in liquidity would weaken the returns by $4.39 \%$. This inverse relationship is consistent with our expectation. Indeed, on average, the sample had upped their liquidity by more than $70 \%$ (refer to Table 1 ). While there is no standard level of liquidity a broiler firm has to keep, its ability to meet short-term obligations is underpinned by a short production cycle (i.e., one month in most modern farms) and fast-moving sales. The turnover process is rapid. Any capital shortfall can also be filled through timely borrowings in this liquid economy. A firm that ramped up its liquid financial position is likely to possess excess capital; forgoing the opportunity that could be achieved by investing the surplus is inherently counter-productive, leading to sub-optimal financial returns. Ensuring liquidity is nonetheless necessary for certain situations and business models. Such an intersection of objectives may explain the inelastic change in financial performance to a change in liquidity.

The operating margin (1.2378) was a highly significant $(\mathrm{p}<0.001)$ managerial characteristic. It had a relatively high association with ROIC: a 10\% improvement in operating efficiency would lift broiler firms' profitability by $12.4 \%$. This positive relationship is consistent with our expectations. In fact, on average, broiler firms' underperformance was coupled with a shrinking efficiency over time (refer to Table 1). In Malaysia's case, as mentioned earlier, the sample continued to produce and market largely commodity-based broiler products. Competition in such a staple market is not only stiff, but is also encumbered with constant monitoring of retail prices by the government and consumer associations. Temporary ceiling prices, which are set reasonably above the sector's average cost of production, are also imposed during festive seasons. With little or no pricing power, the capacity to extract the greatest profit from each quantity sold becomes highly dependent on managerial capability in managing business operations and associated costs. Failing to achieve an efficiency level that is above the sectoral average will result in underperformance. With below-average efficiency, losses occur during price control periods, in which demand peaks typically. Therefore, the change in profitability is almost in proportion to the operating margin. 


\section{DISCUSSION}

Our analysis of the panel data suggested that forward integration is a profitable strategy for Malaysian broiler firms. This may be related to its function allowing forms to gain better control over product quality (Teece, 2010). In cases where partial forward integration occurred, Bell et al. (2002) also found additional profit was generated through a branding exercise. Notwithstanding that, its elasticity measure suggested that broiler firms on a greater downstream value chain development did not earn a commensurate return on their capital investment. In the terminology of financial strategy, this finding may refer to an economic loss for failing to cross a hurdle of the expected rate of return; that is, investment is appealing if it generates a return greater than the cost of invested capital (Mauboussin \& Callahan, 2014). It is tempting to conclude that, but this knowledge might be skewed without directly considering the financial information. Broiler firms should evaluate a specific value chain integration initiative as an independent investment and consider whether it will help increase the average of combined returns or dilute the core competencies. Firms should not initiate a vertical boundary extension unless it creates or protects value (Stuckey \& White, 1993).

The elasticity of forwarding integration discovered in this study can also be compared to that of backward integration and horizontal integration. The positive association between forwarding integration and the financial outcome is noteworthy. Both backward integration and horizontal showed otherwise. In absolute terms, forward integration also had the highest correlation with financial returns, followed by backward integration and horizontal integration.

The findings revealed that the influence of different types of integration is not equal and may be related to their function and price transmission. For backward integration, the function centers on improvements in production efficiency; forward integration is based on quality control; and horizontal integration on byproduct commercialization. They all involve a steep learning curve to attain the intended objective(s). Yet, the upstream segment remains exposed to volatility of international feedstock prices, and the by-products segment operates in a competitive commodity market (Assefa et al., 2015). In particular, price adjustments between feed and farm outputs are based on cost-push transmission and, thus, fairly symmetrical (Ben-Kaabia $\&$ Gil, 2005). However, in the case of lower farm prices, those who own downstream outlets are likely to enjoy a larger price spread through asymmetric price transmission. In a poor market environment, they can also turn offensive by processing fresh broilers into frozen food with a longer shelf-life. Such diversification may help reduce their losses if any (Rahman et al., 2017). At the same time, moving an undifferentiated broiler towards a differentiated form is a salient characteristic of agricultural industrialization, as described by Godwin \& Jones (1971). Therefore, the multifunctionality and attributes (e.g., price transmission and competitiveness) of an integration initiative should be considered.
Importantly, irrespective of their integration strategies and financial strengths, the fact that the largest elasticity measure we obtained in this study was for operating margin. This indicates that efficiency is a greater determinant than other factors of broiler firms' financial performance. Profitability is highly dependent on the capability of their management in operation and cost disciplines. Their strategic importance is also noted for those operating in developed countries (Allen \& Lavau, 2014). From a policy point of view, this finding suggests that measures directed towards encouraging broiler firms and farmers to extend beyond their existing value chain operation should take the importance of efficiency into consideration. For instance, this can be done by associated costs and benefits (Heise et al., 2015). Such project evaluation is of particular relevance since the broiler sector will continue to operate in a commoditybased environment before consumers begin to climb up a product differentiation pyramid. At the same time, value chain integration would make only a limited contribution to strengthening the competitive advantage of broiler firms without a strict efficiency discipline.

Given that pecking order in the effects of integration on revenues, efficiency becomes a priority. This point is reinforced by Tey et al. (2020). Efficiency establishes a solid foundation before it is worthwhile for firms to take on additional investment (risk). Having a proven formula of what works presents a strategic "means" for upscaling, e.g., towards business boundary expansion through value chain integration and/or business intensification through mergers and acquisitions. Such a disciplined investment approach aims to manage risk first, before seeking vertical integration, which is complex and costly to set in place.

Value chain integration is not a panacea. Splitting operators' efforts unnecessarily simply deepen the hole of an inefficient industry trying to dig itself out. Without adequate efficiency at the firm level, policy stimulations seeking to accelerate industrialization through sub-optimal value chain integration will dictate a market structure, i.e., leading to restructuring and consolidation in which a few large winners will take market share from many losers (Ferlito \& Respatiadi, 2018). That unfortunate situation will raise barriers to entry and push the poultry market, which is already increasingly concentrated, to a higher agglomeration level. As a result, the formulation of sectoral industrialization policies should consider both the operational and cost improvement perspectives and how their improved joint efficiency may allow broiler firms to retain more of their sales as profits whilst meeting consumer demand and the national interest. Because integration brings further complexity, the additional challenge of managing efficiency effectively within a specific type of integration investment should not be undermined. Extension services should be readily available to help shorten that learning process.

Nevertheless, the findings of this may face constraints in generalization. First, the degree of integration represents only the presence of firms' integration establishments. Segmental information, such as capacity usage, productivity, and efficiency, may provide more 
insightful knowledge. Second, other intangible resources (e.g., cultures, animal welfare, and sustainability investments) and strategic considerations (e.g., contract farming) may present competitive tools. Third, there are many small and medium-sized broiler firms not covered in this study. Therefore, future studies aiming to understand both policy and business implications of value chain integration should attempt to address these limitations.

\section{CONCLUSION}

The novelty of this study involved understanding the different influences of forward, backward, and horizontal integrations on the financial performance of broiler firms. Based on the 2006-2018 panel data of seven Malaysian broiler firms, profitability was found to be affected by the degree of forward integration, current ratio, and operating margin. These findings show that all types of integration are not equal. Of all the forms of integration studied, only vertical investment in the downstream segment, described as forward integration, was associated with improved returns. However, the return was not commensurate with the degree of forward integration, suggesting limited competitive advantage firms gained from that strategy. Efficiency remains of particular significance to profitability.

\section{CONFLICT OF INTEREST}

We declare that there is no conflict of interest with any financial, personal, or other relationships with other people or organizations related to the material discussed in this study.

\section{REFERENCES}

Abdul Hadi, A. H. I., M. N. Shamsudin, A. Radam, \& J. Selamat. 2013. Consumer preference for food attributes in Malaysia: case studies on broiler and beef. J. Int. Food Agribus Mark. 25: 137-153. https://doi.org/10.1080/089744 38.2013.805453

Allen, J., \& S. Lavau. 2015. 'Just-in-time' disease: biosecurity, poultry and power. J. Cult. Econ. 8: 342-360. https://doi.org /10.1080/17530350.2014.904243

Assefa, T. T., M. P. Meuwissen, \& A. G. O. Lansink. 2015. Price volatility transmission in food supply chains: a literature review. Agribusiness. 31: 3-13. https://doi.org/10.1002/ agr.21380

Baluch, N., A. S. Ariffin, Z. Abas, \& S. Mohtar. 2017. Servitization in Malaysian poultry contract farming: a critical overview. Int. J. Supply Chain Manag. 6: 259-265.

Bamiro, O. M., \& A. M. Shittu. 2009a. Vertical integration and cost behavior in poultry industry in Ogun and Oyo States of Nigeria. Agribusiness. 25:1-15. https://doi.org/10.1002/ agr.20185

Bamiro, O. M., S. Momoh, \& D. O. A. Phillip. 2009b. Vertical integration and profitability in poultry industry in Ogun and Oyo States, Nigeria. J. Hum. Ecol. 27:149-154. https:// doi.org/10.1080/09709274.2009.11906204

Barbut, S. 2016. Poultry Products Processing: an Industry Guide. CRC Press, Boca Raton. https://doi. org/10.1201/9781420031744

Barney, J. 1991. Firm resources and sustained competitive advantage. J. Manage. 17: 99-120. https://doi. org/10.1177/014920639101700108

Bell, D. R., Y. Wang, \& V. Padmanabhan. 2002. An explanation for partial forward integration: Why manufacturers become marketers. Working Paper, The Wharton School, University of Pennsylvania.

Ben-Kaabia, M., J. M. Gil, \& M. Ameur. 2005. Vertical integration and non-linear price adjustments: The Spanish poultry sector. Agribusiness, 21: 253-271. https://doi.org/10.1002/ agr.20046

Bhuyan, S. 2002. Impact of vertical mergers on industry profitability: An empirical evaluation. Rev. Ind. Organ. 20: 67-79.

Bhuyan, S. 2005. Does vertical integration affect market power? Evidence from U.S. food manufacturing industries. Journal of Agricultural and Applied Economics. 37: 263276. https://doi.org/10.1017/S1074070800007240

Blažková, I. \& O. Dvouletý. 2018. The causes of firm performance variation in the Czech food processing industry in the context of the outlier effect. Manag. Res. Rev. 41: 968986. https://doi.org/10.1108/MRR-05-2017-0142

Brilliant, H. \& E. Collins. 2014. Why Moats Matter: the Morningstar Approach to Stock Investing. John Wiley and Sons, New Jersey.

Chaddad, F. R., \& M. P. Mondelli. 2013. Sources of firm performance differences in the US food economy. J. Agr. Econ. 64 382-404. https://doi.org/10.1111/j.1477-9552.2012.00369.x

Chang, W., A. E. Ellinger, K. Kim, \& G. R. Franke. 2016. Supply chain integration and firm financial performance: A meta-analysis of positional advantage mediation and moderating factors. Eur. Manag. J. 34:282-295. https://doi. org/10.1016/j.emj.2015.11.008

Constance, D. H., F. Martinez-Gomez, G. Aboites-Manrique, A. Bonanno. 2013. The Problems with Poultry Production and Processing. In: H. S. James (Ed). The Ethics and Economics of Agrifood Competition. Springer, Dordrecht. p. 155-175. https://doi.org/10.1007/978-94-007-6274-9_8

Damodaran, A. 2007. Return on capital (ROC), return on invested capital (ROIC) and return on equity (ROE): Measurement and implications. Working paper, Stern School of Business. http://people.stern.nyu.edu/adamodar/pdfiles/papers/returnmeasures.pdf. [2 June 2020]. https://doi.org/10.2139/ssrn.1105499

Dobashi, I., J. Fallon, F. C. Eizmendi, M. Loureiro, K. Matchett, R. Parrish, \& B. Raquet. 1999. The Value Chain for Poultry. Working Committee on Food Products, Pacific Basin Economic Council.

Espino-Rodríguez, T. F., \& V. Padrón-Robaina. 2005. A resource-based view of outsourcing and its implications for organizational performance in the hotel sector. Tourism Manag. 26: 707-721. https://doi.org/10.1016/j. tourman.2004.03.013

FAO. 2008. Poultry in the 21st Century: Avian Influenza and Beyond. Proceedings of the International Poultry Conference, held 5-7 November 2007, Bangkok, Thailand. Edited by O. Thieme and D. Pilling. FAO Animal Production and Health Proceedings, No. 9. Rome. http:// www.fao.org/3/a-i0323e.pdf. [15 November 2020].

Ferlito, C. \& H. Respatiadi. 2018. Policy reform on poultry industry in Indonesia. Discussion Paper. Center for Indonesian Policy Studies. https://repository.cipsindonesia.org/media/271878-policy-reform-on-poultryindustry-in-ind-52817e14.pdf [2 June 2020]. https://doi. org $/ 10.35497 / 271878$

Godwin, M. R. \& L.L. Jones. 1971. The emerging food and fiber system: Implications for agriculture. Am. J. Agr. Econ. 53:806-815. https://doi.org/10.2307/1238092

Grau, A. \& A. Reig. 2019. The industry effect and the decision to integrate vertically in a crisis context. Euro. J. Fin. 25:15911605. https://doi.org/10.1080/1351847X.2019.1628795

Grau, A. \& A. Reig. 2020. Operating leverage and profitability 
of SMEs: agri-food industry in Europe. Small Bus. Econ. In press. https://doi.org/10.1007/s11187-019-00294-y

Gschwandtner, A. \& S. Hirsch. 2018. What drives firm profitability? A comparison of the US and EU food processing industry. Manchester Sch. 86:390-416. https://doi. org/10.1111/manc.12201

Heise, H., A. Crisan, \& L. Theuvsen. 2015. The poultry market in Nigeria: Market structures and potential for investment in the market. Int. Food Agribus. Manag. Rev. 18: 197-222.

Henry, R., \& G. Rothwell. 1995. The World Poultry Industry. IFC Global Agribusiness Series. World Bank, Washington D.C. https://doi.org/10.1596/0-8213-3429-8

Hirsch, S., \& J. Schiefer. 2016. What causes firm profitability variation in the EU food industry? A redux of classical approaches of variance decomposition. Agribus. 32: 79-92. https://doi.org/10.1002/agr.21430

Hirsch, S., J. Schiefer, A. Gschwandtner, \& M. Hartmann. 2014. The determinants of firm profitability differences in EU food processing. J. Agr. Econ. 65: 703-721. https://doi. org/10.1111/1477-9552.12061

Hoffmann, I. 2005. Research and investment in poultry genetic resources-challenges and options for sustainable use. World's Poultry Sc. J. 61: 57-70. https://doi.org/10.1079/ WPS200449

Koller, T., R. Dobbs, \& B. Huyett. 2010a. Value: The Four Cornerstones of Corporate Finance. John Wiley and Sons.

Koller, T., M. Goedhart, \& D. Wessels. 2010b. Valuation: Measuring and Managing the Value of Companies. John Wiley and Sons.

Lotterman, E. 1998. Poultry: a quiet success story. Federal Reserve Bank of Minneapolis, Minneapolis. https://www. minneapolisfed.org/article/1998/poultry-a-quiet-successstory. [4 February 2020].

Mauboussin, M. \& D. Callahan. 2014. Calculating return on invested capital. How to determine ROIC and address common issues. Credit Suisse. https://plus.credit-suisse.com/ rpc4/ravDocView?docid=P8BJ3Y. [20 February 2020].

Minkler, A. P. \& T. A. Park. 1994. Asset specificity and vertical integration in franchising. Rev. Ind. Organ. 9:409-423. https://doi.org/10.1007/BF01029514
Monsur, S. M. T. \& T. Yoshi. 2012. Improvement of firm performance by achieving competitive advantages through vertical integration in the apparel industry of Bangladesh. Asian Econ. Fin. Rev. 2: 687-712.

Muazu, U. A., Z. A. Mohamed, M. N. Shamsuddin \& I. Abdulatif. 2016. Measuring Market Power in the Integrated Malaysian Poultry Industry: New Empirical Industrial Organization Approach. J. Food Prod. Mark. 22: 455-470. https://doi.org/10.1080/10454446.2014.885860

OECD. 2018. Market examinations in Mexico: Case study of the chicken meat market. Organization of Economic Cooperation and Development. https://www.oecd.org/ daf/competition/market-examinations-in-mexico-chickenmeat-market-2018.htm. [4 January 2020].

Rahman, M. S., D. H. Jang, \& C. J. Yu. 2017. Poultry industry of Bangladesh: entering a new phase. Korean J. Agr. Sc. 44: 272-282. https://doi.org/10.7744/kjoas.20170027

Rani, N., S. S. Yadav, \& P K. Jain. 2015. Financial performance analysis of mergers and acquisitions: evidence from India. Int. J. Comm. Manag. 24:402-423. https://doi.org/10.1108/ IJCoMA-11-2012-0075

Riethmuller, P. C. \& N. Chalermpao. 2002. Some issues associated with the livestock industries of the AsiaPacific Region. RAP Publication No. 2002/06, Food and Agriculture Organization of the United Nations. http:// www.fao.org/tempref/docrep/fao/005/ac448e/ac448e00. pdf. [2 January 2020].

Saleem, Q. \& R. U. Rehman. 2011. Impacts of liquidity ratios on profitability. Interdiscipl. J. Res. Bus. 1: 95-98.

Stuckey, J. \& D. White. 1993. When and when not to vertically integrate. MIT Sloan Manag. Rev. 34: 71-83.

Teece, D. J. 2010. Forward integration and innovation: Transaction costs and beyond. J. Retail. 86: 277-283. https:// doi.org/10.1016/j.jretai.2010.07.013

Tey, Y. S., M. Brindal, S. Darham, S. F. A. Sidique, \& M. Djama. 2020. Early mover advantage in Roundtable on Sustainable Palm Oil certification: A panel evidence of plantation companies. J. Clean. Prod. 252: 119775. https:// doi.org/10.1016/j.jclepro.2019.119775

Wernerfelt, B. 1984. A resource-based view of the firm. Strateg. Manag. J. 5:171-180.https://doi.org/10.1002/smj.4250050207 